\title{
Relationship Between Serum Adiponectin and Plasma Fatty Acids Composition In Off-Shore (Rig) Workers In Bayelsa State, Nigeria
}

\author{
${ }^{1,}$ Orluwene Chituru Godwill, ${ }^{2,}$ Kasia Benedicta E. \\ ${ }^{1, B}$.Med. Sci; MBBS; FMCPath $\quad{ }^{2}$ MBBS, FMCPath

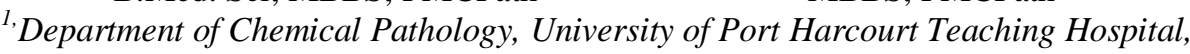 \\ P. M. B. 6173; Port Harcourt, Rivers State, Nigeria. \\ ${ }^{2}$,Department of Chemical Pathology, Niger Delta University Teaching Hospital Okolobiri, \\ Bayelsa State, Nigeria. \\ Correspondence :Department Of Chemical Pathology, University Of Port Harcourt Teaching Hospital \\ P. M. B. 6173, Port Harcourt, Rivers State, Nigeria.
}

\begin{abstract}
The concentration and type of fat in the diet influence the development of obesity and related inflammatory activity. Knowledge of the possible influence of dietary habits on serum adiponectin, a molecule with putative anti-inflammatory properties, maybe helpful in preventing atherosclerosis and type 2 diabetes.The relationship between dietary fat (inferred from plasma fatty acid composition from gas-liquid chromatography) and serum adiponectin (measured by competitiveradioimmunoassay) was evaluated in 70 adult healthy offshore (Rig) workers. The proportion of saturated fatty acids in plasma was significantly associated with serum adiponectin $(r=-0.23 ; P=0.01)$.Specifically, percentage of palmitic acid $(C 16: 0)$ was significantly associated with lower adiponectin concentration $(r=-0.30 ; P=0.001)$, particularly among women $(r=-0.37 ; P=0.01)$ and non-smokers $(r=-0.32 ; P=0.005)$. Percentage of myristicacid $(C 14: 0)$ was also significantly associated with lower adiponectin among non-smokers $(r=-0.26 ; p=0.02)$ and women $(r=-0.40 ; P=0.01)$. The other fatty acids were not significantlyassociated with adiponectin except for eicosanoic acid (C20:1 w-9), which was significantly and positively associated with serum adiponectin in all individuals $(r=0.22 ; P=0.01)$. This latter association was most significant in smokers $(r=0.42 ; P=0.006)$. In a multivariate regression analysis to predict serum circulating adiponectin, after controlling for age, body mass index, waist-to-hip ratio, and the individual remaining fatty acids, the percentages of palmitic acid $(P=0.005)$ andeicosanoic acid $(P=0.02)$ contributed independently (8\% and 5\%, respectively) to adiponectin variance. Among non-smokers, the percentage of palmitic acid $(p=0.01)$ and $w-3$ fatty acids contributed $10 \%$ and $9 \%$ respectively, to adioponectin variance. Among smokers, the percentage of eicosanoic acid $(P=0.03)$ contributed to $12 \%$ of adiponectin variance, independently of body mass index, age, waist-to-hip ratio, and the remaining individual fatty acids. Saturated and w-3 fatty acids of dietary origin (inferred from plasma fatty acid composition) are associated with serum adiponectin concentration in healthy industrial (Rig) workers in Bayelsa State, Nigeria. The proportion of eicosanoic acid also appears to be positively associated with serum adiponectin. The knowledge of how these interactions occur may be helpful in the planning of dietary measures aimed at the modulation of inflammatory activity.
\end{abstract}

KEYWORDS: Serum-Adiponectin, Plasma-fatty-acids, off-shore (Rig)-workers, Bayelsa-state, Nigeria.

\section{INTRODUCTION}

Adipose tissue has been known to secrete a myriad of proteins that are increasingly recognized to influence the metabolism of proteins, carbohydrates and lipids [1]. Adiponectin (also variously called Acrp30 or AdipoQ in mice) is a 244-amino acid protein synthesized and secreted exclusively by adipose tissue [2,3]. This hormone circulates at relatively high concentrations and has a half-life of several hours [4]. This rate of turnover of this hormone is consistent with its role as a regulator of metabolic processes, such as modulation of fat partitioning, among other actions. Administration of adiponectin and/or its globular head portion stimulates free fatty acid oxidation in muscle [5]. High fat feeding leads to decreased Acrp30 secretion in mice [6], whereas caloric restriction leads to higher circulating concentrations of adiponectin in mice and humans [7]. Circulating adiponectin concentrations are also inversely correlated to triglyceride $[8,9]$ and intramyocellular lipid stores [10].

It has been reported that plasma concentrations of adiponectin are lower in obesity and type 2 diabetes $[8,11]$ and that adipose tissue Acrp30/adiponectin mRNA expression is decreased in obese ob/ob mice and obese humans [12].The mechanisms underlying the observed close association between plasma adiponectin 
concentration and lipid metabolism are being elucidated [13, 14]. In vitro and in vivo studies in rodents have shown that adiponectin prevents lipid accumulation in skeletal muscles in parallel to lowering blood glucose and improving insulin action [14]. Some observations suggest that adiponectin could play a role in counteracting the development of diet-induced insulin resistance [6,7]. It is important to note that these actions appear to be independent of the presence of obesity: adiponectin-null mice showed diet-induced insulin resistance despite increases in body weight similar to those in control mice $[15,16]$. The interaction among diet-induced insulin resistance, adiponectin concentrations, and lipid metabolism could be exerted at the level of the inflammatory cascade. The amount and quality of fat in the diet seem to be of related inflammatory activity [17]. A low proportion of long-chain unsaturated fatty acids and a high proportion of saturated fatty acids in the diet have been associated with impaired insulin action [18].Adiponectin possess anti-inflammatory [19] and antiatherogenic properties $[20,21]$. On the other hand, highly unsaturated fatty acids, w-3 fatty acids in particular, are also receiving increasingattention as potential anti-inflammatory agents [22] because these dietary fatty acids appear to modulate the release of different cytokines [23, 24].How dietary fat may impact on peripheral adiponectin concentration, or vice versa, is unknown. One potential pathway is activation of the nuclear receptor peroxisome proliferator-activated receptor-y (PPAR-y) [1]. In fact, fatty acids activate PPAR-y [25], and pharmacologic activation with PPAR-y agonists leads to increased plasma adiponectin concentrations [26, 27]. Knowledge of the possible influence of dietary habits on circulating adiponectin concentrations could be helpful in delineating dietary measures aimed at preventing type 2 diabetes. However, studies of the associations etween dietary habits in relation to the development of chronic diseases are hampered by severalmethodologic problems, includingimprecision of dietary surveys [18]. One way to monitor the type of fat in the diet is to record the fatty acid composition in plasma [18]. Our aim was to evaluate the relationship or association between dietary habits, as inferred from plasma fatty acid composition, and circulating adiponectin (serum adiponectin) in off-shore (Rig) "healthy" workers especially as this group of individuals are on special company-provided meals.

\section{SUBJECTS AND METHODS}

We evaluated 70 individuals as part of the periodic medical examination for offshore (Rig) industrial workers in the Niger Delta region (BayelsaState, in particular) of Nigeria. This particular examination also involved screening for metabolic syndrome and assessment of non-classical cardiovascular risk factors in the working population, given the fact that they are all exposed to the same special company-provided offshore meals. All the workers involved are blacks and from Niger Delta region of Nigeria (particularly, Bayelsa State). All those involved in the study reported to maintaining a steady body weight for at least 3 months before the study. None was taking any medication or had any evidence of metabolic disease apart from obesity.Inclusion criteria for the study were (1) a body mass index (BMI) $<40 \mathrm{~kg} / \mathrm{m}^{2},(2)$ absence of any systemic disease, and (3) absence of any infection in the previous month. The study was approved by the Niger Delta University Teaching Hospital ethics committee, and informed consent was obtained from all the participants and management of the companies involved.Body mass index (BMI) and waist-to-hip ratio (WHR) were measured in all participants. BMI was calculated as weight (in kilograms) divided by the height (in meters) squared. The waist-to-hip ratio was gotten by measuring the waist circumference with a soft tape placed midway between the lowest rib and the iliac crest and dividing the value gotten with that of the hip circumference gotten using the same tape to measure the widest part of the gluteal region.Smokers were defined as any person consuming at least one cigarette a day in the previous 6 months. Resting blood pressure (BP) was taken from all participants using the Accouson's Mercury Sphygmomanometer after participants has been in a sitting position for a minimum of $15 \mathrm{~min}$. The blood pressure was read thrice in the right arm by the same investigator and the mean of the three measurements was recorded for this study. All the female participants were pre-menopausal, had regular menstrual cycles and were studied in their follicular phase. Liver disease and thyroid dysfunction were specifically excluded from this study by biochemical workup.Following the method of Lepage and Roy [28], we precisely weighed $100 \mu 1$ of plasma obtained after a 12-hour fast into an Ethylene Diamine Tetra-acetic Acid (EDTA) specimen container and diluted the plasma with methanol-benzene (4:1 by volume). Slowly added acetyl chloride (200 $\mu$ l) over a period of $1 \mathrm{~min}$. after transesterification, we dried the pooled solvent extracts under a gentle stream of nitrogen at room temperature. Residues were dissolved in $500 \mu$ l of hexane, an aliquot chromatographed as methylesters on a 30-m fussed-silica column (0.25min i.d.). Analysis was performed on a Hewlett-Packard 5890 gas chromatograph equipped with a flame ionization detector. The column temperature was held at $80^{\circ} \mathrm{C}$ for $3 \mathrm{~min}$ and then increased in a stepwise fashion to a plateau of $220^{\circ} \mathrm{c}$. The injection port and detector temperatures were 250 and $270^{\circ} \mathrm{C}$, respectively. Helium was used as carrier gas. An internal standard consisting of $50 \mu \mathrm{g}$ of pentadecanoic acid (C15:0) was precisely weighed and added to the serum. 
Serum adiponectin concentrations were measured by competitive Radioimmunoassay (LINCO Research Inc.). Samples were diluted 500-fold ( $10 \mu 1$ of plasma plus $4990 \mu 1$ of assay buffer) before the assay. The detection limit of the method is $2 \mu \mathrm{g} / \mathrm{L}$. the intra-and interassay coefficient of variations $(\mathrm{CVs})$ were $<5 \%$.Fasting plasma glucose concentration was measured in duplicate by the glucose oxidase method. The specimen for this assay was collected in the fluoride oxalate specimen container. Serum insulin concentration for all participants was measured in duplicate by a monoclonal immunoradiometric assay (IRMA) (Medgenix Diagnostics). The lower limit of detection for insulin was $4.0 \mathrm{mIU} / \mathrm{L}$. The intraassay CV was $5.2 \%$ at a concentration of $10 \mathrm{mIU} / \mathrm{L}$ and the interassay $\mathrm{CV}$ was $6.9 \%$ at $14 \mathrm{mIU} / \mathrm{L}$. The fasting insulin resistance index [Homeostasis model assessment (HOMA) was calculated with the formular: HOMA = fasting glucose $(\mathrm{mmol} / \mathrm{L})$ $\mathrm{X}$ fasting insulin (mIU/L) / 22.5. HOMA correlates well with insulin resistance index calculated by the minimal model approach: $\mathrm{r}=0.79 ; \mathrm{P}<0.0001$ [29]. Total plasma cholesterol was measured by the reaction of cholesterol esterase/cholesterol oxidase/peroxidase (Enzymatic method). Total triglycerides were measured through the reaction of glycerol-3-phosphate oxidase and peroxidase (Enzymatic method).

\section{STATISTICAL METHODS}

Descriptive results for continuous variables are expressed as the mean (SD). Before statistical analysis, guassian distribution and homogeneity of variances were tested. Variables that did not fulfill these tests (individual fatty acids and ratios, HOMA, adiponectin) were log-transformed. The relationships between variables were analyzed by simple correlation analysis (Pearson, $r$ ). We set statistical significance at $\mathrm{P} \leq 0.05$ and have based our discussion on these relationships. We also constructed a stepwise multivariate linear regression analysis to predict adiponectin concentrations, taking into consideration those variables with statistical association of at least $\mathrm{P}<0.01$ on univariate analysis. Because in a previous work we found that smoking affected the relationship between inflammatory markers and metabolic variables [30], we also examined whether smoking (defined as at least I cigarette/day in the previous 6 months) affected adiponectin relationships.

\section{RESULTS}

The main characteristics and serum fatty acid composition of the study participants are shown in Tables 1 and 2. The absolute fatty acid concentration did not differ significantly between men and women. Serum adiponectin was significantly higher in women than men $(P=0.005$; Table 1$)$. The proportion of saturated acids tended to be lower and the proportion of oleic acid (C18:1 $\omega-9)$ tended to be higher among the female workers (Table 1). The proportion of eicosanoic acid (C20:1 $\omega-9)$ was significantly higher in women than men (Table 1). Plasma adiponectin correlated negatively with BMI $(\mathrm{r}=-0.21 ; \mathrm{P}=0.02)$, WHR $(\mathrm{r}=-0.25 ; \mathrm{P}=0.001)$ and fasting triglycerides $(\mathrm{r}=-0.36 ; \mathrm{P}=0.0001)$ and tended to be associated with HOMA value $(\mathrm{r}=-0.14 ; \mathrm{P}=0.06)$. Serum adiponectin was not significantly associated with age, systolic or diastolic blood pressure, fasting glucose, or cholesterol.

The proportion of saturated fatty acids was significantly associated with circulating adiponectin concentrations ( $\mathrm{r}=-0.23 ; \mathrm{P}=0.01$; Table 3$)$. Particularly, the proportion of palmitic acid (C16:0) was significantly inversely associated with adiponectin concentration $(\mathrm{r}=-0.30 ; \mathrm{P}=0.001)$. This association wassignificantly mainly among women $(\mathrm{r}=-0.37 ; \mathrm{P}=0.01)$ and in non-smokers $(\mathrm{r}=-0.32 ; \mathrm{P}=0.005)$. The proportion of myristicacid (C14:0) was also significantly inversely associated with adiponectin among non-smokers $(\mathrm{r}=$ $0.26 ; \mathrm{P}=0.02)$ and in women $(\mathrm{r}=-0.40 ; \mathrm{P}=0.01)$ The other individual fatty acids were not significantly associated withadiponectin except for eicosanoic acid (C20:1 $\omega-9)$, which was significantly and positively associated with adiponectin in all participants $(\mathrm{r}=0.22 ; \mathrm{P}=0.01)$. This latter association was most significant in smokers $(\mathrm{r}=0.42$; $\mathrm{P}=0.006)$. C20:1 $\omega-9$ was the only fatty aid that was significantly increased in smokers compared with nonsmokers (Table2). Total monounsaturated $\omega-9$ fatty acids were also significantly associated with adiponectin among smokers (Tables 3). The proportion of $\omega-3$ fatty acids tended to be positively associated with adiponectin in non-smokers $(\mathrm{r}=0.20 ; \mathrm{P}=0.06)$. The ratio of saturated $(\omega-3)$ fatty acids correlated positively with both HOMA value $(\mathrm{r}=0.18 ; \mathrm{P}=0.02)$ and serum adiponectin concentrations $(\mathrm{r}=0.18 ; \mathrm{P}=0.02)$. We performed several multivariate regression analyses to predict circulating adiponectin concentrations. In these models, we considered as independent variables those individual fatty acids that showed a relationship with at least $\mathrm{P}<0.1$ on univariate analysis. After controlling for age, BMI, WHR (which persisted in the model), and the individual remaining fatty acids, only the proportions of palmitic acid $(\mathrm{C} 16: 0 ; \mathrm{P}=0.005)$ and eicosanoic acid $(\mathrm{C} 20: 1 \omega-9$; $\mathrm{P}=0.03)$ contributed independently to adiponectin variance ( $8 \%$ and $5 \%$ respectively).Among non-smokers, and after again controlling for age, BMI, WHR (which persisted in the model), and the remaining individual fatty acids, only the proportions of palmitic acid $(\mathrm{C} 16: 0 ; \mathrm{P}=0.01)$ and $\omega-3$ fatty acids contributed to adiponectin variance $(10 \%$ and $9 \%$, respectively). 
Among smokers, only the proportion of eicosanoicacid (C20:1 $\omega-9 ; \mathrm{P}=0.02)$ contributed to adiponectin variance (12\%), independently of BMI, age, WHR, and the remaining individual fatty acids. Of the remaining factors, only WHR persisted in the model.

\section{DISCUSSION}

The proportions of fatty acids in plasma mirror the dietary fat composition. The relationships between the amount of polyunsaturated fatty acids in the diet and the corresponding proportions of the same fatty acids in plasma lipids are often strong [18]. This is usually true for essential fatty acids, such as linolenic and linoleic acids. However, most other types of fatty acids can be synthesized by humans from precursors, particularly saturated fatty acids.

Adiponectin was found to be negatively associated with the main saturated fatty acid, palmitic acid (C16:0). In an in-vitro study, saturated fatty acids induced activation of nuclear factor-kB, an important mediator in the production of several cytokines [31], whereas docosahexanoic acid (DHA; C22:6) counteracted these effects [31,32]. The possible actions of saturated fatty acids on adiponectin production have not been evaluated. Our findings suggest that increased intake of saturated fatty acids and increased endogenous transformation of fatty acids that leads to increased concentrations of saturated fatty acids in plasma are associated with decreased serum adiponectin concentrations. This study could not derive the cause and consequence but it could be hypothesized that decreased serum adiponectin concentrations amplify the proinflammatory action of saturated fatty acids. Adiponectin was positively associated with the proportion of C20:1 $\omega$-9. This association was especially significant in smokers $(\mathrm{P}=0.006)$. Although BMI tended to be lower with increased proportions of $\mathrm{C} 20: 1 \omega-9$, the association remained significant after controlling for BMI ( $\mathrm{r}$ $=0.24, \mathrm{P}=0.006$ ). Significantly increased products of delta-9 desaturation and significant increases in $\mathrm{C} 20$ elongation products have been observed in rats with reduced food intake [33]. On the other hand, smoking has been found to be associated with a decreased proportion of essential fatty acids [34], and essential fatty acid deficiency leads to a characteristic increase in $\omega-9$ fatty acids [35]. Since caloric restriction can lead to higher circulating concentrations of adiponectin in mice and humans [7], it is tempting to speculate that reduced food intake leads to increased adiponectin and C20:1w-9 concentrations concomitantly. We found, secondly that those individuals with an increased proportion of C18:3 $\omega-9$ had concomitantly decreased serum adiponectin concentrations. The content of this fatty acid is typically very small in diet. It reflects increased endogenous desaturation of linoleic acid by delta- 6 desaturase, increasing the proportion of C18:3 $\omega-6$, probably as a consequence of a low proportion of linoleic acid in the diet [18]. Our findings suggest that low intake of this essential fatty acid could lead to increased C18:3 $\omega-6$ and concomitant decreased adiponectin concentrations.

We showed that the proportion of $\omega-3$ fatty acids in general, and DHA in particular, were highest in those individuals with increased circulating adiponectin. In non-smokers, this association persisted after controlling for age, BMI, WHR, and the remaining individual fatty acids. Interestingly, two putative antiinflammatory molecules, $\omega-3$ fatty acids and adiponectin, seem to be linked. The same processes and dietary habits that increase the concentrations of $\omega-3$ fatty acids lead to concomitant increasedadiponectin concentrations. Novel functional sets of lipid-derived mediators with anti-inflammatory action generated from $\omega-3$ fatty acids have been increasingly recognized [22]. The association of the proportions of $\omega-3$ and adiponectin described here seems particularlyimportant in light of findings in American women: increased intake of the $\omega-3$ polyunsaturated fatty acids eicosapentanoic (C20:5 $\omega-3)$ and DHA (C22:6 $\omega-3)$ was associated with reduced risk of thrombotic diseases [26]. In parallel with these observations, the authors of invivo and in-vitro studies in humans reported that supplementation witheicosapentanoic acid and DHA appeared to reduce cytokine production $[23,24,31,36,37,38]$. The above relationships were most likely to have a dietary explanation because food is the major source of these fatty acids [18]. Adiponectin also has antiatherogenic properties and inhibits proliferation of vascular smooth muscle cell [16]. Inflammation in the vessel wall plays a major role in the initiation and progression of atherosclerosis $[39,40]$. Decreased adiponectin concentrations have been observed in patients with coronary artery disease [8]. The findings of the present study suggest that all these associations are interrelated events.An association between concentrations of fasting plasma triglycerides and serum adiponectin has also been observed [9]. Other studies have shown that adiponectin promotes lipid oxidation in humans, with a subsequent decrease in intracellular lipid content in human muscle [10]. These results are consistent with animal data: Adiponectin was shown to enhance lipid oxidation and decrease the concentration of muscle triglycerides [5, 13].Our study is limited by the fact that our findings are hypothesis-generating. It will be necessary to demonstrate that adiponectin concentrations can be modulated by ingestion of certain fatty acids or by changing of serum fatty acid composition. In addition, fatty acids were measured in plasma even when it is well known that fatty acids were also major components of cell 
membranes.Fatty acids measured in cell membranes may better reflect longer-term dietary fatty acids intake because fatty acid turnover may be slower in cell membranes than in plasma.

\section{CONCLUSION}

Saturated and $w$-3fatty acids of dietary origin (reflected in and inferred from plasma fatty acid concentration) are associated with serum adiponectin concentrations in healthy industrial (Rig) workers. The proportion of C20:1 w-9 also appears to be positively associated with serum adiponectin. Adequate knowledge of how these interactions occur will be helpful in the planning of dietary measures aimed at the modulation of inflammatory activity.

Table 1: Anthropometric and Biochemical Characteristics of the subjects.

Parameter

Number

Age, years

Weight, Kg

$\mathrm{BMI}, \mathrm{Kg} / \mathrm{m}^{2}$

WHR

$\mathrm{SBP}, \mathrm{mmHg}$

DBP, $\mathrm{mmHg}$

FPG, mmol/L

FSI, mIU/L

HOMA Score

Cholesterol, $\mathrm{mmol} / \mathrm{L}$

Triglycerides, $\mathrm{mmol} / \mathrm{L}$

Adiponectin, mg/L

Fatty acids, \% of total fatty acids:

14:0

16:0

$16: 1(\omega-9)$

18:0

$18: 1(\omega-9)$

$18: 2(\omega-6)$

$18: 3(\omega-6)$

$18: 3(\omega-3)$

20:0
Men

45

39.2(10.1)*

77.1(9)

24.7(2.8)

$0.95(0.03)$

125.8(12)

75.1(10)

4.6(0.4)

7.0(4.0)

1.45(0.7)

5.5(1.1)

1.3(0.7)

15.2(3.8)

$0.43(0.25)$

21.0(2.1)

$0.36(0.8)$

7.70(0.70)

19.7(2.6)

30.2(4.7)

$0.43(0.13)$

$0.25(0.1)$

$0.28(0.06)$

\section{Women}

25

$35.4(8.9)$
$59.8(10.5)$
$22.9(3.9)$
$0.86(0.05)$

NS 0.0001

0.01

0.0001

118.4(14)

0.006

67.1(7.3)

0.001

4.2(0.5)

0.02

6.9(4.1)

NS

$1.30(0.7)$

NS

5.1(1.0)

0.03

$0.7(0.3)$

0.0001

18.5(4.3)

0.005

$0.50(0.35) \quad$ NS

20.5(4.0) NS

$0.36(0.9) \quad$ NS

$7.40(1.0) \quad$ NS

$21.8(8.0) \quad 0.07$

29.5(6.0) NS

$0.42(0.15) \quad$ NS

$0.31(0.4) \quad$ NS

$0.26(0.07) \quad$ NS 
Relationship Between Serum Adiponectin...

Table 2: Plasma fatty acid components in relation to smoking status of subjects

\begin{tabular}{|c|c|c|c|}
\hline \multirow[t]{2}{*}{ Fatty acid* } & \multicolumn{2}{|c|}{ Relative concentration, \% } & \multirow[b]{2}{*}{ P-value } \\
\hline & Non-smokers $(n=48)$ & Smokers $(n=22)$ & \\
\hline 14:0 & $0.42(0.27)$ & $0.47(0.35)$ & NS \\
\hline $16: 0$ & $19.8(2.1)$ & $19.6(3.0)$ & NS \\
\hline $16: 1(\omega-9)$ & $0.31(0.09)$ & $0.31(0.08)$ & NS \\
\hline 18:0 & $7.80(0.61)$ & $7.52(1.0)$ & NS \\
\hline $18: 1(\omega-9)$ & $20.6(3.5)$ & $21.8(7.0)$ & 0.06 \\
\hline $18: 2(\omega-6)$ & $30.2(4.1)$ & $29.8(6.0)$ & NS \\
\hline $18: 3(\omega-6)$ & $0.41(0.12)$ & $0.40(0.14)$ & \\
\hline \multicolumn{4}{|l|}{ NS } \\
\hline $18: 3(\omega-3)$ & $0.25(0.09)$ & $0.31(0.34)$ & NS \\
\hline 20:0 & $0.28(0.05)$ & $0.26(0.06)$ & NS \\
\hline $20: 1(\omega-9)$ & $0.10(0.07)$ & $0.21(0.15)$ & 0.013 \\
\hline $20: 3(\omega-6)$ & $1.36(0.3)$ & $1.50(0.31)$ & NS \\
\hline $20: 4(\omega-6)$ & $7.16(1.27)$ & $7.01(1.29)$ & NS \\
\hline $20: 5(\omega-3)$ & $0.54(0.40)$ & $0.53(0.39)$ & NS \\
\hline $22: 0$ & $0.82(0.16)$ & $0.80(0.14)$ & NS \\
\hline $22: 6(\omega-3)$ & $2.00(0.58)$ & $1.92(0.54)$ & NS \\
\hline 24:0 & $1.02(0.14)$ & $1.00(0.18)$ & NS \\
\hline $24: 1(\omega-9)$ & $1.21(0.31)$ & $1.20(0.28)$ & NS \\
\hline Essential fatty acids & $44.1(4.9)$ & $42.9(6.2)$ & NS \\
\hline Saturated fatty acids & $31.7(1.8)$ & $29.9(3.5)$ & 0.09 \\
\hline Monounsaturated & $23.3(3.5)$ & $23.0(3.2)$ & NS \\
\hline Polyunsaturated, $\omega-3$ & $2.67(0.7)$ & $2.60(0.8)$ & NS \\
\hline Polyunsaturated, $\omega-6$ & $37.6(4.8)$ & $36.9(5.7)$ & NS \\
\hline
\end{tabular}


Table 3: Showing correlation between plasma fatty acid components and Adiponectin

\begin{tabular}{|c|c|c|c|c|c|c|c|c|c|c|}
\hline \multirow[t]{2}{*}{ Fatty acids } & \multicolumn{2}{|c|}{$\begin{array}{l}\text { All subjects } \\
(\mathbf{n}=70)\end{array}$} & \multicolumn{3}{|c|}{$\begin{array}{l}\text { Men } \\
(n=45)\end{array}$} & $\begin{array}{l}\text { Women } \\
(\mathbf{n}=25)\end{array}$ & \multicolumn{2}{|c|}{$\begin{array}{c}\text { Non-smokers } \\
(n=48)\end{array}$} & \multicolumn{2}{|c|}{$\begin{array}{c}\text { Smokers } \\
(n=22)\end{array}$} \\
\hline & $\mathbf{r}$ & $\mathbf{P}$ & $\mathbf{r}$ & $\mathbf{P}$ & $\mathbf{r}$ & $\mathbf{P}$ & $\mathbf{r}$ & $\mathbf{P}$ & $\mathbf{r}$ & $\mathbf{P}$ \\
\hline $14: 0$ & -0.10 & 0.3 & -0.01 & 0.7 & -0.40 & 0.01 & -0.26 & 0.02 & 0.05 & 0.6 \\
\hline $16: 0$ & -0.30 & 0.001 & -0.09 & 0.4 & -0.37 & 0.01 & -0.32 & 0.005 & -0.20 & 0.1 \\
\hline $16: 1(\omega-9)$ & 0.04 & 0.6 & -0.05 & 0.5 & -0.03 & 0.7 & 0.05 & 0.4 & 0.001 & 0.9 \\
\hline 18:0 & 0.07 & 0.3 & 0.15 & 0.1 & 0.12 & 0.3 & 0.02 & 0.6 & 0.20 & 0.1 \\
\hline $18: 1(\omega-9)$ & 0.07 & 0.3 & 0.08 & 0.4 & 0.01 & 0.8 & 0.03 & 0.7 & 0.23 & 0.3 \\
\hline $18: 2(\omega-6)$ & -0.01 & 0.8 & -0.10 & 0.3 & 0.16 & 0.25 & 0.04 & 0.5 & -0.20 & 0.1 \\
\hline $18: 3(\omega-3)$ & 0.01 & 0.7 & -0.05 & 0.6 & -0.002 & 0.9 & 0.04 & 0.7 & -0.10 & 0.4 \\
\hline $20: 0$ & .0 .03 & 0.6 & 0.03 & 0.7 & 0.20 & 0.1 & 0.01 & 0.7 & 0.08 & 0.2 \\
\hline $20: 1(\omega-9)$ & 0.22 & 0.01 & 0.13 & 0.1 & 0.15 & 0.3 & 0.5 & 0.6 & 0.42 & 0.006 \\
\hline $20: 3(\omega-6)$ & 0.08 & 0.30 & 0.10 & 0.3 & 0.21 & 0.1 & 0.05 & 0.6 & 0.18 & 0.1 \\
\hline $20: 4(\omega-6)$ & 0.01 & 0.68 & 0.02 & 0.7 & 0.10 & 0.5 & 0.10 & 0.3 & -0.1 & 0.4 \\
\hline $20: 5(\omega-3)$ & 0.07 & 0.3 & 0.07 & 0.3 & 0.10 & 0.3 & 0.06 & 0.3 & 0.11 & 0.2 \\
\hline $22: 0$ & 0.10 & 0.1 & 0.11 & 0.3 & 0.14 & 0.10 & 0.13 & 0.2 & 0.05 & 0.1 \\
\hline $22: 6(\omega-3)$ & 0.05 & 0.3 & 0.06 & 0.3 & 0.08 & 0.4 & 0.11 & 0.3 & -0.01 & 0.5 \\
\hline $24: 0$ & 0.05 & 0.3 & 0.08 & 0.4 & 0.11 & 0.3 & 0.06 & 0.4 & 0.03 & 0.4 \\
\hline $24: 1(\omega-9)$ & 0.06 & 0.5 & -0.001 & 0.8 & 0.23 & 0.1 & 0.07 & 0.4 & -0.01 & 0.4 \\
\hline EFA & 0.01 & 0.8 & -0.06 & 0.5 & 0.21 & 0.1 & 0.10 & 0.3 & -0.20 & 0.7 \\
\hline SFA & -0.23 & 0.01 & -0.04 & 0.6 & -0.30 & 0.04 & -0.20 & 0.07 & -0.1 & 0.3 \\
\hline MUSFA ( & $\omega-9) 0.07$ & 0.2 & 0.08 & 0.4 & 0.01 & 0.8 & 0.02 & 0.8 & 0.34 & 0.001 \\
\hline PUSFA $(\omega$ & 2-3)0.07 & 0.2 & 0.08 & 0.4 & 0.10 & 0.5 & 0.20 & 0.06 & 0.001 & 0.8 \\
\hline PUSFA $(\omega$ & a-6)0.001 & 0.7 & -0.07 & 0.4 & 0.19 & 0.2 & 0.06 & 0.3 & -0.21 & 0.1 \\
\hline $\begin{array}{l}\text { EFA=Esse } \\
\text { PI ISFA =P }\end{array}$ & tial fat & acid & SFA & atur & FA, & & $A=$ & Monol & aturated & FA, \\
\hline
\end{tabular}

\section{REFERENCES}

[1]. Fernandez-Real JM, Ricart W. Insulin resistance and chronic cardiovascular inflammatory syndrome. Endocr Rev 24, 2003, 278301.

[2]. Maeda K, Okubo K, Shimomura I, Funahashi T, Matsuzawa Y, Matsubara K. cDNA cloning and expression of a novel adipose specific collagen-like factor, apM1 (AdiPose Most abundant Gene transcript 1), BiochemBiophys Res Commun 221, 1996, 286289.

[3]. Scherer PE, Williams S, Fogliano M,Baldini G, Lodish HF. A novel serum protein similar to C1q, produced exclusively in adipocytes. J. BiolChem 270, 1995, 26746-26749.

[4]. Hoffstedt J, Arvidsson E, Sjolin E, Wahlen K, Arner P. Adipose tissue adiponectin production and adiponectin serum concentration in human obesity and insulin resistance. J ClinEndocrinolMetab 89, 2004, 1391-1396.

[5]. Fruebis J, Tsao TS, Javorschi S, Ebbets-Reed D, Erickson MR, Yen FT, et al. Proteolytic cleavage product of 30-KDa adipocyte complement-related protein increases fatty acid oxidation in muscle and causes weight loss in mice. ProcNatiAcadSci USA 98 2001, 2005-2010.

[6]. Yamauchi T, Kamon J, Waki H, Terauchi Y, Kubota N, Hara K, et al. The fat-derived hormone adiponectin reverses insulin resistance associated with both lipoatrophy and obesity. Nat Med 7, 2001, 941-946. 
[7] Berg AH, Combs TP, Du X, Brownlee M, Scherer PE. The adipocytes-secreted protein Acrp30 enhances hepatic insulin action. Nat Med 7, 2001, 947-953.

[8] Hotta K, Funahashi T, Arita Y, Takahashi M, Matsuada M, Okamoto Y, et al. Plasma concentrations of a novel, adipose-specific protein, adiponectin in type 2 diabetic patients. AeteriosclerThrombVascBiol 20, 2000, 1595-1599.

[9] Matsubara M, Maruoka S, Katayose S. Decreased plasma adiponectin concentrations in women with dyslipidemia. $J$ ClinEndocrinolMetab 87, 2002, 2764-2769.

[10] Thamer C, Machann J, Tschritter O, Haap M, Wietek B, Dahl D, et al. Relationship between serum adiponectin concentration and intramyocellular lipid stores in humans. HormMetab Res 34, 2002, 646-649.

[11] Weyer C, Funahashi T, Tanaka S, Hotta K, Matsuzawa Y, Pratley RE, et al. Hypoadiponectinemia in obesity and type 2 diabetes: close association with insulin resistance and hyperinsulinemia. J ClinEndocrinolMetab 86, 2001, 1930-1935.

[12] Hu E, Liang P, Spiegeiman BM. AdipoQ is a novel adipose-specific gene dysregulated in obesity. J BiolChem 271, 1996, 1069710703.

[13] Yamauchi T, Kamon J, Minokoshi Y, Ito Y, Waki H, Uchida S, et al. Adiponectin stimulates glucose utilization and fatty-acid oxidation by activating AMP-activated protein kinase.Nat Med 8, 2002, 1288-1295.

[14] Tomas E, Tsao TS, SahaAk, Murrey HE, Zhang Cc C, Itani SI, et al. Enhanced muscle fat oxidation and glucose transport by ACRP30 globular domain:acety-CoA carboxylase inhibition and AMP-activated protein kinase activation. ProcNatiAcadSci USA 99, 2002, 16309-16313.

[15] Maeda N, Shimomura I, Kishida K, Nishizawa H, Matsuda M, Nagaretani H, et al. Diet-induced insulin resistance in mice lacking adiponectin. Nat Med 8, 2002, 731-737.

[16] Kubota N, Terauchi Y, Yamauchi T, Kubota T, Moroi M, Matsui J, et al. Disruption of adiponectin causes insulin resistance and neointimal formation. J BiolChem 277, 2002, 25863-25866.

[17] Ferna'ndez-Real JM, Broch M, Vendrell J, Ricart W. Insulin resistance, inflammation and serum fatty acid composition. Diabetes Care 26, 2003, 1362-1368.

[18] Vessby B. Dietary fat, fatty acid composition in plasma and the metabolic syndrome. CurrOpinLipidol 14, 2003, 15-19.

[19] Yokota T, Oritani K, Takahashi I, Ishikawa J, Matsuyama A, Ouchi N, et al. Adiponectin, a new member of the family of soluble defense collagens, negatively regulates the growth of myeolomocytic progenitors and the functions of macrophages. Blood 96 , 2000, 1723-1732.

[20] Ouchi N, Kihara S, Arita Y, Maeda K, Kuriyama H, Okamoto Y, et al. Novel modulator of endothelial adhesion molecules: adipocyte-derived plasma protein adiponectin. Circulation 100, 1999, 2473-2476.

[21] Ouchi N, Kihara S, Arita Y, Okamoto Y, Maeda K, Kuriyama H, et al. Adiponectin, an adipocyte-derived plasma protein, inhibits endothelial NK-kB signaling through a camp-dependent pathway. Circulation 102, 2000, 1296-1301.

[22] Serhan CN, Clish CB, Brannon J, Colgan SP, Chiang N, Gronert K. Novel functional sets of lipid-derived mediators with antiinflammatory actions generated from omega-3 fatty acids via cyclooxygenase 2-nonsteroidal anti-inflammatory drugs and transcellular processing. JExp Med 192, 2000, 1197-1204.

[23] Meydani SN. Modulation of cytokine production by dietary polyunsaturated fatty acids.ProcSocExpBiol Med 200, 1992, 189193.

[24] Endres S, Ghorbani R, Kelly VE, Georgilis K, Lonnemann G, van der Meer JW, et al. The effect of dietary supplementation with $\mathrm{n}-3$ polyunsaturated fatty acids on the synthesis of interleukin-1 and tumor necrosis factor by mononuclear cells. $N$ Engl J Med 320, 1989, 265-271.

[25] Krey G,Braissant O, L'Horset F, Kalkhoven E, Perroud M, Parker MG, et al. Fatty acids, eicosanoids, and hypolipidemic agents identified as ligands of peroxisome proliferator-activated receptors by coactivator-dependent receptor ligant assay. MolEndocrinol 11, 1997, 779-791.

[26] Maeda N, Takahashi M, Funahashi T, Kihara S, Nishizawa H, Kishida K, et al PPARyligands increase expression and plasma concentrations of adiponectin, an adipose-derived protein. Diabetes 50, 2001, 2094-2099.

[27] Miyazaki Y, Mahankali A, Wajcberg E, Bajaj M, Mandarino LJ, DeFronzo RA. Effect of piogilitazone on circulating adipocytokine levels and insulin sensitivity in type 2 diabetic patients.JClinEndocrinolMetab 89, 2004, 4312-4319.

[28] Lepage G, Roy CC. Direct transesterification of all classes of lipids in a one-step reaction. J Lipid Res 27, 1986, 114-120.

[29] Fernandez-Real JM, Molina A, Broch M, Ricart W, Gutierrez C, Casamitjana R, et al. The TNF system activity is associated with insulin resistance and dyslipidemia in myotonic dystrophy. Diabetes 48, 1999, 1108-1112.

[30] Fernandez-Real JM,Vayreda M, Ricart C, Gutierrez C, Broch M, Vendrell J, et al. Circulating interleukin 6 levels, blood pressure, and insulin sensitivity in apparently healthy men and women. J ClinEndocrinolMetab86, 2001 1154-1159.

[31] Lee JY, Sohn KH, Rhee SH, Hwang D. Saturated fatty acids, but not unsaturated fatty acids, induce the expression of cyclooxygenase-2 mediated through toll-like receptor 4. J BiolChem 276, 2001, 16683-16689.

[32] De Caterina R, Liao JK, Libby P. Fatty acid modulation of endothelial activation. Am J ClinNutr 71, 2000, 213-223.

[33] Kramer TR, Briske-Anderson M, Johnson SB, Holman RT. Influence of reduced food intake on polyunsaturated fatty acid metabolism in zinc-deficient rats. $J$ Nutr 114, 1984, 1224-1230.

[34] LengGC, Smith FB, Fowkes FG, Horrobin DF, Ells K, Morse-Fisher N, et al. Relationship between plasma essential fatty acids and smoking, serum lipids, blood pressure and haemostatic and rheological factors. Prostaglandins LeukotEssentFatty Acids 51, 1994, 101-108.

[35] Soriguer F, Moreno F, Rojo-Martinez G, Garcia-Fuentes E, Tinahones F, Gomez-Zumaquero JM, et al. Monounsaturated n-9 fatty acid and adipocyte lipolysis in rats. Br J Nutr 90, 2003, 1015-1022.

[36] Iso H, Rexrode KM, Stampfer MJ, Manson JE, Colditz GA, Speizer FE, et al. Intake of fish and omega-3 fatty acids and risk of stroke in women. JAMA 285, 2001, 304-312.

[37] Khalfoun B, Thibault F, Watier H, Bardos P, Lebranchu Y. Doccosahexaenoic and eiocosapentaenoic acids inhibit in vitro human endothelial cell production of interleukin-6.AdvExp Med Biol400B, 1997, 589-597.

[38] Loppnow H, Libby P. Comparative analysis of cytokine induction in human vascular endothelial and smooth muscle cells. Lymphokine Res 8, 1989, 293-299.

[39] Seino Y, Ikeda U, Ikeda M, Yamamoto K, Misawa Y, Hasegawa T, et al. Interleukin-6 gene transcripts are expressed in human atherosclerotic lesions. Cytokine 6, 1994, 87-91.

[40] Ridker PM, Rifai N, Stampfer MJ, Hennekens CH. Plasma concentration of interleukin-6 and the risk of future myocardial infarction among apparently healthy men. Circulation 101, 2000, 1767-1772. 